as that collected by Cohn and Gohi, and on sending a specimen to the last-named botanist he confirmed the correctness of the diagnosis.

Mixed with the Minnesota Algæ named above were fragments of an Anabana, which appeared to be the form commonly known as A. Flos-aqua, var. circinalis, and also traces of a larger $A n a-$ bena, the species of which could not be made out. In the Boston water works at South Framingham, Mass., Anabcena gigantea, Wood, was found in small quantity in the early part of November, 1882. I would also record the discovery of Nostochopsis lobata, Wood, by Messrs. E. Faxon and F. H. Hosford, at Ferrisburg, Vt., where it was comparatively abundant and formed expansions of several inches in water-courses. The occurrence of Sphceroploea annulina should be recorded in California, where it was collected by Mrs. Austin near San Bernardino.-W. G. FARLOW.

\title{
General Conditions of Spontaneous Protoplasmic Movement.
}

Dr. Chas. S. Dolley, of Rochester, N. Y., has just translated Th. W. Engelmann's paper upon the "Phvsiology of Protoplasmic Motion," which has attracted so much attention. The following are the general statements under the above caption:

1. Temperature. - For all contractile protoplasm there is a higher and a lower temperature at which the spontaneous movements cease under all circumstances. The minimum lies mostly in the neighborhood of $0^{\circ}$, the maximum generally about $40^{\circ}(\mathrm{C})$.

2. Hygroscopicity.-In regard to this it is the same as regarding the temperature. There is, for all protoplasm, a maximum and minimum eapacity for the inhibition of water. Close determination is wanting, yet the minimum may average below 60 per cent., and the maximum over 90 per cent. Within these limits the energy of the movements increases in general with the amount of contained water, with a corresponding increase of volume, and diminution of the refractive coefficient. Rapid change in concentration of the medium, causing rapid swelling, or more specially shriveling, acts in a manner similar to irritants.

3. OXYGEN.-P'rotoplasmic motion is undoubtedly able to continue in a medium entirely free from oxygen, but for a short time only, at the most, some hours. The gradual stagnation can at first be overcome by the introduction of oxygen, and by this means alone. 


\section{$2 \mathrm{BHL}$ Biodiversity Heritage Library}

1883. "General Conditions of Spontaneous Protoplasmic Movement." Botanical gazette 8(5), 225-225. https://doi.org/10.1086/325699.

View This Item Online: https://www.biodiversitylibrary.org/item/27484

DOI: https://doi.org/10.1086/325699

Permalink: https://www.biodiversitylibrary.org/partpdf/221441

\section{Holding Institution}

New York Botanical Garden, LuEsther T. Mertz Library

\section{Sponsored by}

MSN

\section{Copyright \& Reuse}

Copyright Status: NOT_IN_COPYRIGHT

This document was created from content at the Biodiversity Heritage Library, the world's largest open access digital library for biodiversity literature and archives. Visit BHL at https://www.biodiversitylibrary.org. 